\title{
The new Geothermal Energy: Science, Society, and Technology
}

\author{
Olaf Kolditz ${ }^{1,2}$, Luis Carlos Gutiérrez-Negrín ${ }^{3}$, Ernst Huenges ${ }^{4}$, Leslie Jakobs ${ }^{1 *}$, Thomas Kohl ${ }^{5}$ and Inga Moeck ${ }^{6}$
}

\author{
${ }^{*}$ Correspondence: \\ leslie.jakobs@ufz.de \\ ${ }^{1}$ Helmholtz Centre \\ for Environmental Research - \\ UFZ, Leipzig, Germany \\ Full list of author information \\ is available at the end of the \\ article
}

In light of the recent worldwide move to reduce dependence on coal and nuclear energy, renewable energies have taken on significant importance on a global level. Geothermal energy offers considerable future potential for heating and cooling (near-surface geothermal energy) as well as electricity production (deep geothermal energy also known as enhanced/engineered geothermal systems [EGS]), and there still remain many open questions.

To shift the topic of geothermal energy more strongly into the focus of scientific research and development, two open-access journals formed simultaneously in 2013, both focusing on the science behind geothermal energy: Geothermal Energy and Geothermal Energy Science.

As such, the editors of both journals recognized that the journals covered the same scope and would be stronger by cooperating rather than competing. The editors thus agreed to merge the journals into one to combine efforts and build on each other's strengths. To preserve the Scopus listing already achieved by Geothermal Energy, the decision was made to keep the journal name Geothermal Energy. A new subtitle to the journal-Science, Society, and Technology-differentiates it from the former, but preserves the Scopus listing. The newly merged journal's launch date was 01 July 2017, and the transition from the former journal to the new one was smooth and unnoticeable. All articles published under Geothermal Energy are still and always will be available at the journal website.

Geothermal Energy: Science, Society, and Technology now bears a new title, cover and has the support of both scientific institutions (UFZ, GFZ, KIT) and professional organizations, including the leading international organization in geothermal research, the International Geothermal Association (IGA), and the leading geothermal organization in Germany, the German Geothermal Association (BVG).

We are proud to present to you this new, stronger journal and, with increasing interest in and demand for renewable technologies, have high expectations for Geothermal Energy: Science, Science, and Technology.

\footnotetext{
Abbreviations

IGA: International Geothermal Association; BVG: German Geothermal Association; UFZ: Helmholtz Centre for Environmental Research; GFZ: German Research Centre for Geosciences; KIT: Karlsruhe Institute of Technology.
}

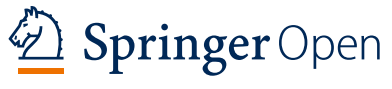

(c) The Author(s) 2017. This article is distributed under the terms of the Creative Commons Attribution 4.0 International License (http://creativecommons.org/licenses/by/4.0/), which permits unrestricted use, distribution, and reproduction in any medium, provided you give appropriate credit to the original author(s) and the source, provide a link to the Creative Commons license, and indicate if changes were made. 
Authors' contributions

OK and $\amalg$ wrote the editorial, while all other authors proofed for accuracy. All authors read and approved the final manuscript.

\section{Author details}

${ }^{1}$ Helmholtz Centre for Environmental Research - UFZ, Leipzig, Germany. ${ }^{2}$ TU Dresden, Dresden, Germany. ${ }^{3}$ International Geothermal Association, Bochum, Germany. ${ }^{4}$ German Research Centre for Geosciences (GFZ), Potsdam, Germany.

${ }^{5}$ Karlsruhe Institute of Technology, Karlsruhe, Germany. ${ }^{6}$ German Geothermal Association (BVG), Berlin, Germany.

\section{Acknowledgements}

Not applicable.

\section{Competing interests}

The authors declare that they have no competing interests.

\section{Funding}

Topic "Geothermal Energy Systems" within the Helmholtz Program "Renewable Energies".

\section{Publisher's Note}

Springer Nature remains neutral with regard to jurisdictional claims in published maps and institutional affiliations.

Received: 26 September 2017 Accepted: 5 October 2017

Published online: 19 October 2017

\section{Submit your manuscript to a SpringerOpen ${ }^{\circ}$} journal and benefit from:

- Convenient online submission

Rigorous peer review

- Open access: articles freely available online

- High visibility within the field

Retaining the copyright to your article

Submit your next manuscript at $\boldsymbol{\Delta}$ springeropen.com 